\title{
EVALUATION OF ANTI-CCP ANTIBODIES AND RHEUMATOID FACTOR FOR THE LABORATORY DIAGNOSIS OF RHEUMATOID ARTHRITIS
}

\author{
NAWFAL Y. AL-DABBAGH, BSC, MSC, PHD* \\ ZHARA A. HASHIM, BSC, MSC **
}

\section{Submitted 20/12/2017; accepted 25/5/2018}

\section{ABSTRACT}

Background: 1-Assess the correlation between Anti-cyclic citralliuated peptide (anti-CCP2) antibodies concentration with some clinical and laboratory parameters of rheumatoid arthritis (RA): 2-Evaluate the differences in the clinical and serological parameters between anti$\mathrm{CCP}^{2+v e}$ and anti-CCP ${ }^{2-v e}$ patients and Rheumatoid factor $\left(\mathrm{RF}^{+\mathrm{ve}}\right.$ and $\left.\mathrm{RF}^{-\mathrm{ve}}\right)$ patients. 3-Assess the relationship between smoking history and the detection of anti-CCP2 and RF auto antibodies.

Subject and Methods: This is a case-control study carried out on 55 patients with established RA attending the Rheumatology ward of Ibn-Sina Teaching Hospital in Nineveh Governorate during the period from $1^{\text {st }}$ November 2010 to the $1^{\text {st }}$ June 2011 and 35 apparently healthy individuals as a control. Anti-CCP2 antibodies were measured using enzyme linked immunosorbent assay (ELISA).The RF was tested by latex agglutination and ELISA. C-reactive protein (CRP) was measured by Latex agglutination test. Patients' demographic data, disease activity and duration and erythrocyte sedimentation rate (ESR) were also recorded

Results: Anti-CCP2 antibodies were found significantly associated with RF, total swollen joints (TSJ) and total tender joints (TTJ) counts $(\mathrm{p}<0.05)$ while the correlation with ESR, CRP, disease activity score 28 (DAS28) and disease duration was not significant ( $p>0.05$ ). In RA patients with smoking history and joints deformity, anti-CCP2antibodies was more often detected. The same results were obtained for RF seropositivity. It was also found that the differences between $\mathrm{RF}^{+v e}$ and $\mathrm{RF}^{-v e}$ groups were comparable to those between anti-CCP2 ${ }^{+v e}$ and anti-CCP-2ve groups except for ESR and CRP.

Conclusions: The study suggests that the seropositivity of RF is inflammation driven, whereas, the appearance of anti-CCP antibodies might suggests pathophysiological properties and a possible contribution to on-going immune activation

Duhok Med J 2018; 12 (1): 41-54

Keywords: RF, RAanti-CCP2 antibody, DAS28, score, rheumatoid factor, rheumatoid arthritis.

\begin{aligned} & \hline R heumatoid arthritis (RA) is the most an interaction between genetic and \\ & common inflammatory joint disease environmental factors ${ }^{2}$. The diagnosis of \\ & with prevalence between 0.5 and $1 \%^{\text {RA is mainly based on clinical signs and }} \\ &$ worldwide ${ }^{1}$. The precise etiology of RA is $\begin{array}{l}\text { symptoms according to latest } \\ \text { recommendations of the American College }\end{array} \\ &$ unknown but it has been suggested to be \end{aligned}

* Assistant Professor, Department of Medical Analysis Technique, El-Kitab University College, Kirkuk, Iraq.

** Assistant lecture, Department of Pharmacology, College of Pharmacy, University of Mosul, Mosul, Iraq.

Correspondence author to: Nawfal Y. Al-Dabbagh, nawfal.y.aldabbagh@gmail.com, Mobil +9647707404444

Recent research was conducted in Dept. of Microbiology, College of Medicine, University of Mosul, Mosul, Iraq. 
of Rheumatology (ACR) in $1987^{3}$. Within the seven ACR classification criteria, detection of $\operatorname{IgM}(\mathrm{RF})$ in serum is the only recommended laboratory marker. Though IgM-RF is measured in most studies and is the most often ordered autoantibody test in laboratory diagnosis, its specificity for diagnosing RA is limited; at very low levels, IgM-RF is present in sera of most people High concentrations of IgM-RF are not only detected in RA but also in other conditions with polyclonal stimulation to B-cells like viral and bacterial infections or chronic inflammations other than $\mathrm{RA}^{4}$. The need for a better laboratory marker with a higher disease-related specificity and sensitivity was always evident. Therefore, a new approach for classification of RA was introduced in 2010by the ACR and the European League against Rheumatism ${ }^{5}$. In the "new "criteria, serology and autoimmune diagnostics carry a major weight, as detection of cyclic citrullinated peptide is appropriate to diagnose the disease in an early state, before joints destructions occur ${ }^{6}$. An additional connection between smoking and anticitrulline auto-antibodies provides further potential insight into mechanisms of disease evolution ${ }^{7}$. Cyclic citrullinated peptide (CCP) IgG antibodies have been described as highly specific for $\mathrm{RA}^{8}$. Rheumatoid factors and anti-CCP antibodies have been shown to be useful diagnostic tools particularly in the early stages of the disease and predictive of disease progression ${ }^{9}$. Moreover, an antiCCP antibody appears to be a good prognostic marker that helps in discriminating between erosive and nonerosive disease ${ }^{10}$. The disease activity score 28 (DAS28) is used to assess the disease course and treatment outcome and is based on a count of 28 specified joints for swelling and tenderness, ESR or Creactive protein (CRP) which are the disease activity markers ${ }^{11}$.

\section{MATERIAL AND METHODS}

In this case-control study, 55 RA patients recruited from Rheumatology Ward of Ibn-Sina Teaching Hospital in Nineveh Governorate and 35 healthy age and sex matched subjects with no inflammatory, infectious or arthritic conditions were compared over a period extended from $1^{\text {st }}$ November 2010 to $1^{\text {st }}$ June 2011. There were 50 females and 5 males in the case group and 32 females and 3 males in the control group. The age of the patients ranged from 20-70 years and that of the controls from 21-67 years. The patients were diagnosed as having RA for at least 1 year. The clinical diagnosis was made by an attending rheumatologist according to the 1987 ACR revised criteria.

Anti-CCP antibodies were detected using a commercial IgG anti-CCP enzyme linked immunosorbent assay kit (Aeskulisa, Germany), following the manufacturer's instructions. Briefly, microliter plates were incubated for 30 minutes at room temperature with serum samples diluted at 1:101 in sample buffer. Prediluted antiCCP standards and positive and negative controls were added to each plate. After three washes with washing buffer solution, anti-human immunoglobulins conjugated to horseradish peroxidase (conjugate) were incubated and reacted with the antigenantibody complex of the samples in the micrplpates. After three further washes, addition of the TMB-substrate generates an enzymatic colorimetric (blue) reaction, 
which was stopped by diluted acid (color change to yellow) and the plates were read at $450 \mathrm{~nm}$ (optionally 450/620 nm) with automated device within 30 minutes. AntiCCP antibodies were considered positive when the absorbance value was higher than the cut-off of the kit $(18 \mathrm{U} / \mathrm{ml})$. The rate color formation from the chromogen is a function of the amount of conjugate bound to the antigen-antibody complex and this is proportional to the initial concentration of the respective antibodies in the patient sample.

IgM-Rheumatoid factor was detected by ELISA kit (DRG instruments $\mathrm{GmbH}$, Germany). The principle of the test is similar to that of anti-CCP. According to the manufacturer's instructions, IgM-RF level $<20 \mathrm{U} / \mathrm{ml}$ was considered normal while a level > $20 \mathrm{U} / \mathrm{ml}$ was considered elevated.

Immuno-agglutination tests were used for the qualitative and semi quantitative determination of $\mathrm{RF}$ and $\mathrm{C}$ 1-reactive protein (CRP) according to the manufacturer's instruction using Plasmatic Laboratory Products (Dorset, DT6 5BU, United Kingdom).

ESR was calculated in $\mathrm{mm} / 1^{\text {st }}$ hour unite ${ }^{12}$. Disease activity score28 (DAS28-ESR) was calculated using online calculator by entering the data of tender joint count, swollen joint count of 28 specified joints and ESR for each patient. DAS28 score of higher than 5.1 is indicative of high disease activity, below 3.2 indicates low disease activity and lower than 2.6 is considered remission ${ }^{11}$.

All data were expressed as a mean \pm SD using standard statistical methods. The statistical methods used for the analysis of the obtained data include unpaired t-test, $\mathrm{z}$ - test of one proportion, Pearson correlation and Chi-square test. The statistical test results were considered significant at $\mathrm{p}<$ $0.05^{13}$.

\section{RESULTS}

This study involved fifty five (55) RA patients; their mean age \pm standard deviation (SD) was $47.7 \pm 10.9$ years (ranged 20-70 years). Fifty out of 55 $(90.9 \%)$ were females and $5 / 55$ were males $(9.09 \%)$. The disease duration of these patients had a mean \pm SD of $7.08 \pm 6.96$ years. Thirteen patients $(23.63 \%)$ had a positive family history for RA. Ten patients out of 55 (18.18\%) had a positive smoking history. Controls included 35 subjects with a mean age and standard deviation of 45.2 \pm 9 years (ranged 21- 67 years) and comprised of 3 males $(8.5 \%)$ and 32 females $(91.5 \%)$. The results of the DAS28 calculation based on ESR (DAS28-ESR) showed that 53/55 patients had high disease activities with a mean \pm SD of $5.92 \pm 1.13$.

The laboratory characteristics obtained in the study showed that the anti-CCP2 antibodies were detected in $31 / 55$ $(56.36 \%)$ of RA patients and in $1 / 35$ $(2.85 \%)$ of the controls with a significant difference between the two groups $(\mathrm{p}=0.004)$. The concentration mean $\pm \mathrm{SD}$ was 195.6 $\pm 126.5 \mathrm{U} / \mathrm{ml}$. The IgMrheumatoid factor antibodies detected by ELISA (RF-ELISA) were found positive in $32 / 55(58.18 \%)$ RA patients and among $6 / 35(17.5 \%)$ of the controls with a high significant difference between the two groups $(p=0.009)$. The concentration mean \pm SD of RF-ELISA was $310 \pm 233.2$ $\mathrm{U} / \mathrm{ml}$ and $26.25 \pm 6.8 \mathrm{U} / \mathrm{ml}$ for the cases and controls respectively. Rheumatoid factor 
antibodies detected by latex agglutination (RF-latex) were found positive in 29/55 $(52.72 \%)$ patients and in $3 / 35(8.5 \%)$ of the control. The difference between the patients and control groups was highly significant $(p=0.000)$. The concentration mean \pm SD of the RF-latex test results was $217.3 \pm 195.9 \mathrm{U} / \mathrm{ml}$ and $4.57 \pm 2.2 \mathrm{U} / \mathrm{ml}$ for the patients and controls respectively. Creactive protein was found $\geq 6 \mathrm{mg} / \mathrm{L}$ in $48 / 55(87.27 \%)$ of the RA patients and in $4 / 35(11.4 \%)$ of the controls. The difference was also significant between the two groups $(p=0.04)$. The concentration mean \pm SD was $36.6 \pm 35.95 \mathrm{mg} / \mathrm{l}$ and $4.37 \pm 4.95 \mathrm{mg} / 1$ for the patients and controls respectively. ESR was measured for patients only and had a mean \pm SD of $48.36 \pm 25.11 \mathrm{~mm} / \mathrm{hr}$.

\section{The correlation between anti-CCP2} antibodies with other parameters of the disease: The concentration of anti-CCP2 antibodies tested in the 55 RA patients showed statistically no significant correlation with ESR and CRP ( $p=0.15$, 0.35 respectively). However, a significant correlation was noted between anti-CCP2 antibody concentration and RF-ELISA, RF-latex concentration $(p=0.023,0.021$ respectively).

The anti-CCP2 antibodies concentration had no significant correlation with disease duration and DAS28 ( $\mathrm{p}=0.102,0.16$ respectively) although there was a high significant correlation between anti-CCP2 antibodies concentration and the total swollen joints 28 (TSJ) count, total tender joints 28 (TTJ) count $(\mathrm{p}=0.000,0.002$ respectively).

Differences in the clinical and serological parameters in the anti-CCP2 seropositive and anti-CCP2 seronegative patients: The data presented in Table 1, showed significant differences between anti-CCP2 seropositive andanti-CCP2 seronegative groups concerning the age, male gender percentage, smoking history and family history $(\mathrm{p}=0.000,0.03,0.02$, 0.03 respectively), however; no significant difference was found in the female gender percentage between the two groups $(\mathrm{p}=0.45)$. The laboratory tests including ESR and CRP in anti-CCP2 seropositive and anti-CCP2 seronegative groups showed no significant difference $(\mathrm{p}=0.240$, 0.39 respectively), though; high significant differences were found in RF-latex and RF-ELISA both in positivity and concentration in the two groups of antiCCP2 status $(p=0.01,0.000$ for RF-latex and $0.012, \quad 0.000$ for RF-ELISA respectively). Table $\mathbf{1}$, also showed high significant differences for DAS28, TSJ count and hand joints deformities between the two groups of anti-CCP2 status ( $\mathrm{p}=0.005,0.003$ and 0.04 respectively).

$\mathbf{R F}^{+v e}$ and RF-ve groups vs. anti-CCP+ve and anti-CCP-ve groups: Significant differences were noticed between positive and negative patients for anti-CCP2 antibodies and RF-ELISA regarding DAS28 and smoking history $(\mathrm{p}<0.05)$. However, RF positive patients differ significantly from RF negative patients in regard to CRP concentration and ESR ( $\mathrm{p}=0.008,0.05$ respectively) while no such differences were noted in the two antiCCP2 status as presented in Table 2. Moreover, this study showed that 10/55 $(18.18 \%)$ of the patients had positive smoking history and 8 patients out of them $(80 \%)$ were anti-CCP2 seropositive, with a significant difference between the positive and negative anti-CCP2 groups $(\mathrm{p}=0.02)$. 
The concentration mean of anti-CCP2 antibodies was higher in smokers than non- smokers $(259.7 \mathrm{U} / \mathrm{ml}$ vs. $162.45 \mathrm{U} / \mathrm{ml}$ respectively, $\mathrm{p}=0.01$ ).

For RF, 6 out of 10 smokers were RF positive with a significant difference between positive and negative RF groups (60\% vs. $40 \%$; $\mathrm{p}=0.04$ ), Table 8 . The mean $\mathrm{RF}$ concentration in smoker was higher than for non-smoker (443.03 U/ml vs. $289.29 \mathrm{U} / \mathrm{ml}$ respectively, $\mathrm{p}=0.03)$.

Table 1: Difference in clinical and serological parameters in anti-CCP2 seropositive versus anti-CCP2 seronegative patients

\begin{tabular}{|c|c|c|c|c|}
\hline $\begin{array}{l}\text { Groups } \\
\text { Parameters }\end{array}$ & Total No. & $\begin{array}{c}\text { Anti-CCP2-ve } \\
(\text { No.=31) }\end{array}$ & Anti-CCP2-ve (No.=24) & p-value \\
\hline Age $($ Mean \pm SD $)$ & 55 & $50.22 \pm 10.64$ & $44.4 \pm 10.50$ & $\mathbf{0 . 0 0 0}^{*}$ \\
\hline $\begin{array}{l}\text { Gender }(\%) \\
\text { Male } \\
\text { Female }\end{array}$ & $\begin{array}{c}5 \\
50\end{array}$ & $\begin{array}{c}4(80 \%) \\
27(54 \%)\end{array}$ & $\begin{array}{c}1(20 \%) \\
23(46 \%)\end{array}$ & $\begin{array}{c}0^{0.03}{ }^{* *} \\
0.45 \text { (NS) }\end{array}$ \\
\hline $\begin{array}{l}\text { Positive smoking } \\
\text { history(\%) }\end{array}$ & 10 & $8(80 \%)$ & $2(20 \%)$ & $0.02^{* *}$ \\
\hline Positive family history & 13 & $9(69.2 \%)$ & $4(30.76 \%)$ & $\mathbf{0 . 0 3}^{* *}$ \\
\hline ESR $($ Mean \pm SD $)$ & 55 & $53.16 \pm 23.82$ & $42.166 \pm 25.89$ & $0.240^{*}(\mathrm{NS})$ \\
\hline $\operatorname{CRP}^{+\mathrm{ve}}(\%)$ & 48 & $29(60.4 \%)$ & $19(39.5 \%)$ & $\mathbf{0 . 3 9}^{* *}(\mathrm{NS})$ \\
\hline $\mathrm{CRP}^{+\mathrm{ve}}(\mathrm{Mean} \pm \mathrm{SD})$ & 48 & $44.27 \pm 35.36$ & $37.26 \pm 37.39$ & $0.501^{*}(\mathrm{NS})$ \\
\hline RF-latex ${ }^{+v e}\left(M^{\prime}{ }_{ \pm}+S D\right)$ & 29 & $25(86.2 \%)$ & $4(13.79 \%)$ & $0.01^{* *}$ \\
\hline RF-latex ${ }^{+v e}(\%)$ & 29 & $226.56 \pm 193.03$ & $160 \pm 235.15$ & $\mathbf{0 . 0 0 0}^{*}$ \\
\hline RF-ELIS $^{\text {+ve }}(\%)$ & 32 & $28(87.5 \%)$ & $4(12.5 \%)$ & $0.012^{* *}$ \\
\hline $\begin{array}{l}\text { RF-ELIS } \\
(\text { Mean } \pm \text { SD })\end{array}$ & 32 & $324.37 \pm 228.4$ & $209.43 \pm 278.04$ & $0.000^{*}$ \\
\hline Disease duration $($ Mean \pm SD) & 55 & $9.27 \pm 7.44$ & $4.25 \pm 5.17$ & $0.001^{*}$ \\
\hline DAS28 $($ Mean \pm SD $)$ & 55 & $6.35 \pm 0.94$ & $5.38 \pm 1.15$ & $0.005^{*}$ \\
\hline TSJ count $($ Mean \pm SD) & 55 & $13.16 \pm 6.68$ & $8.25 \pm 4.7$ & $\mathbf{0 . 0 0 3}^{*}$ \\
\hline Joint deformities (\%) & 15 & $9(60 \%)$ & $6(40 \%)$ & $0.04^{*}$ \\
\hline
\end{tabular}

p- Value $\leq \mathbf{0 . 0 5}$ was considered significant by unpaired t-test $(*)$ and $z$-test of one proportion $(* *)$, NS=non-significant

The correlation between DAS28 and other laboratory parameters

There was a significant correlation between DAS28 and the acute phase reactants (ESR and CRP) with a p-value of 0.000 and 0.03 respectively.
There was also a significant correlation between DAS28 and RF-ELISA and RFlatex $(p=0.001,0.005$ respectively), no significant correlation was found betweenDAS28 and Anti-CCP ( $\mathrm{p}=0.16)$ (Table 3). 
Table 2: $2 \mathrm{RF}+\mathrm{ve}$ and RF-regroups vs. anti-CCP+ve and anti-CCP-ve groups

$\begin{array}{cccccc}\text { IgM-RF } & \text { IgM-RF } & \text { p-value } & \text { Anti-CCP2 } & \text { Anti-CCP2 } & \text { p-value } \\ + \text { +ve } & \text {-ve } & & +v e & -v e & \end{array}$

Number of cases

32

23

$0.32 * *(N S)$

31

24

$0.31^{* *}(\mathrm{NS})$

Age $($ Mean \pm SD)

$\begin{array}{lll}50.84 \pm 11.03 & 43.3 \pm 9.2 & 0.00^{*}\end{array}$

$50.22 \pm 10.64 \quad 44.4 \pm 10.50$

0.000*

Disease duration

(Mean+SD)

$$
\begin{array}{lll}
9.45 \pm 7.6 & 3.78 \pm 4.24 & 0.001^{*}
\end{array}
$$

$9.27 \pm 7.44$

$4.25 \pm 5.17$

0.001*

ESR $($ Mean \pm SD)

$53.75 \pm 26.12 \quad 40.86 \pm 22.1 \quad 0.052^{*}$

$53.16 \pm 23.82 \quad 42.16 \pm 25.89$

$0.240 *(\mathrm{NS})$

CRP+ve(Mean \pm SD)

$\begin{array}{lll}50.48 \pm 3 \$ & 24 \pm 28.3 & 0.008^{*}\end{array}$

$44.27 \pm 35.36 \quad 37.26 \pm 37.39$

$0.501 *(\mathrm{NS})$

DAS28 (Mean+SD)

$6.27 \pm 0.95$

$5.39 \pm 1.2 \quad 0.007^{*}$

$6.35 \pm 0.94$

$5.38+1.15$

$0.005^{*}$

Smoking history(\%)

$6 / 10(60 \%)$

4/10(40\%) $\quad 0.04^{* *}$

8/10 (80\%)

$2 / 10(20 \%)$

0.02*

NS=non-significant $p$-value was considered significant by unpaired t-test $(*)$ and z-test of one proportion(**)

\begin{tabular}{|c|c|c|c|c|c|}
\hline \multicolumn{7}{|c|}{ Table 3: 3 Correlation between DAS28 and other laboratory parameters of RA patients } \\
\hline $\begin{array}{c}\text { Parameters } \\
\text { (mean+SD) } \\
\text { DAS28 } \\
(\text { mean } \pm \text { SD) }\end{array}$ & Anti-CCP2 & RF-ELISA & RF-latex & ESR & CRP \\
\hline $5.92 \pm 1.13$ & $195.6 \pm 126.5$ & $310 \pm 233.2$ & $217.3 \pm 195.9$ & $48.36 \pm 25.11$ & $36.6 \pm 35.95$ \\
\hline$*$ p-value & $0.16(\mathrm{NS})$ & 0.001 & 0.005 & 0.000 & 0.03 \\
\hline
\end{tabular}

NS= non-significant, *p-value $<0.05$ was considered significant by Pearson Correlation 


\section{DISCUSSION}

The frequencies of anti-CCP2 antibodies, RF-ELISA and RF-latex positive results were $56.36 \%, \quad 58.18 \%$ and $52.72 \%$ of the patientsrespectively and their frequencies in the control group were $2.85 \%, 17.5 \%$ and $8.5 \%$ respectively with a significant difference between cases and controls. The values of these tests were also higher in the RA patients than in the controls with a significant difference. These results demonstrate the value of anti-CCP and RF antibodies in predicting the presence of RA which is in agreement with previous studies ${ }^{14,15}$. Although RF occurs in $70-90 \%$ of patients with established RA, however; populationbased studies demonstrated lower rates of RF positivity ${ }^{4}$. For anti-CCP antibodies, there are some variations in the results among different studies ranging from $33 \%-87.2 \%^{15}$ and these variations in sensitivity could be due to different cut-off value, difference in serum dilution, difference in detection technique among reports or difference in unit of expression, differences in disease duration and other clinical characteristics of the groups being tested $^{16}$.

Our study demonstrated that CRP levels were also significantly higher in patients compared to controls. Similarly, Milovanoic et $a l^{17}$ observed high values of CRP indicative of active inflammation in RA patients. It has been shown in our study that 7 patients $(12.7 \%)$ had normal CRP levels despite having active disease states and this is in accordance with the finding that CRP is normal in up to about $40 \%$ of patients with RAas reported by others $^{18}$.
The anti-CCP antibodies test had been proved by many studies to be useful in identifying those patients who are likely to have clinically significant disease activity $^{16}$. However, no significant correlation was found in this study between anti-CCP2 antibodies concentration and markers of disease activity (ESR, CRP and DAS28). These results are comparable to those stated by other reports ${ }^{15}$. A possible interpretation of such results is that the study design (casecontrol) precludes detection of an association of changes in anti-CCP titer and disease parameters. Furthermore, this study did not account accurately for multiple different medications received by the patients. Finally, the study sample size precludes identification of a small association between anti-CCP antibody concentration and RA clinical and serological parameters and subjected to possible selection bias. On the other hand, anti-CCP2antibodies concentration found, in the current study, to be significantly correlated with TSJ and TTJ counts similar to the findings reported by others ${ }^{19}$.

The present finding that anti-CCP2 antibody antibodies does not correlate with inflammatory markers (ESR and CRP) but with the clinical presentation of the disease (TSJ and TTJ count) indicates that antiCCP antibodies might have an effect, could be a pathophysiological, that involved in RA development ${ }^{20}$, and the lack of a significant correlation with DAS28-ESR score might be due to the effect of ESR on the ,DAS28 when calculating it as it was reported, in a study by Makinen et $a l^{21}$, that in real-life patients, ESR had the greatest effect on DAS28 followed by TJC and SJC. 
This study revealed a significant correlation between anti-CCP and RF by latex and ELISA. These results are compatible with the finding of previous studies ${ }^{15,22}$. It has been proposed that the presence of anti-CCP antibodies correlates with, but does not completely coincide, the presence of $\mathrm{RF}^{23}$.

In this study, no significant correlation was observed between anti- CCP 2 and disease duration, such result is in accordance with the finding of other investigators ${ }^{24}$. In contrast, other studies ${ }^{25}$ proposed that antiCCP value elevates in proximity to disease onset. The reasons for these discrepancies are not clear and need further exploration.

It was found that there was no significant difference between anti-CCP2positive and anti-CCP2 negative patients comparing ESR and CRP. On the other hand, a significant difference was found between the two groups regarding DAS28 and TSJ count as anti-CCP2 seropositive group had greater values of these parameters. These could provide us with further information that anti-CCP seropositive patients might express a different clinical form of RA judged against patients lacking these antibodies. The results ofdifferent studies were varied. Two reports showed that antiCCP seropositive patients had more active disease than anti-CCP seronegative patients $^{26,27}$.

Rheumatoid factor positivity and level were significantly different between antiCCP2 seropositive and anti-CCP2 seronegative groups by the two methods of detection used in the current study. This result is in accordance with many other studies $^{15}$. In other studies of sera obtained before onset ofRA ${ }^{25}$, anticitrulline antibodies were observed prior to the occurrence of RFsuggesting that the increase in RF titers might, in some of these cases, be an event secondary to anticitrulline impunity and immune complex formation involving citrullinated antigens $^{28}$.

Concerning demographical data; age and disease duration were significantly higher in anti-CCP2 positive than anti-CCP2 negative groups. Ronnelid et $a l^{27}$, found that $3.9 \%$ of RA patients changed their anti-CCP status from negative to positive with time. This might suggest that, with advanced age or progression of disease onset, anti-CCP status become more frequently seropositive and this might explain why anti-CCP positive group had higher age comparing with negative one.

The present study showed that 13 out of 55 RA patients had positive family history for RA; nine out of these $13(69.2 \%)$ were anti-CCP2 positive and 4/13 (30.76\%) were anti-CCP2 negative which revealed a significant difference between the two groups. This result matches with the fact that anti-CCP antibodies were associated with HLA-DRB1 SE as a genetic risk factor for RA development ${ }^{29}$.

In general, by comparing the data concerning age, disease duration, ESR, CRP, DAS28 and smoking history obtained in the present study for the positive and negative status between antiCCP and RF antibodies, the results showed that almost all the differences between anti-CCP2 positive and anti- CCP2 negative groups were fairly comparable to those between RF positive and RF negative groups with the exception that ESR and CRP (inflammatory markers) were significantly different between RF positive and RF negative groups but there 
was no significant difference between antiCCP positive and anti-CCP negative groups, again, for ESR and CRP. These results might suggest that the presence of $\mathrm{RF}$ is inflammation driven, whereas, the appearance of anti-CCP antibodies suggests patho-physiological properties and a possible contribution to on-going immune activation ${ }^{20}$.

The frequency of RA patients involved in this study who were smokers or exsmokers was $18.18 \%$. The frequency of smokers in anti- CCP2 positive group was found to be significantly higher than in anti-CCP2 negative group ( $80 \%$ vs. $20 \%$ respectively). This is in accordance with some studies that imply a strong association between smoking and antiCCP antibodies formation ${ }^{30}$. In addition, the present study showed that the mean anti-CCP2 antibodies titer was higher for smokers than non-smokers $(259.7 \mathrm{U} / \mathrm{ml}$ vs. $162.45 \mathrm{U} / \mathrm{ml}$ respectively). However, the presence of high anti-CCP2 titer among members of the current non-smokers group might indicate that other environmental factors contribute to anti-CCP formation ${ }^{31}$. Regarding RF, a higher frequency of RFELISA positive patients was found in the smoker group than non- smoker $(60 \%$ vs. $40 \%$ respectively) comparably with the findings of other investigators ${ }^{32}$. The mean RF level in smokers, like anti- CCP2, was higher than non-smokers $(443.025 \mathrm{U} / \mathrm{ml}$ vs. $289.29 \mathrm{U} / \mathrm{ml}$ respectively). This is in accordance with the study of Padyukov et $a l^{33}$.

In this study, almost all patients were active with a significant association of DAS28 with inflammatory markers (ESR and CRP). These results correlate with previous findings ${ }^{15,34}$. However, DAS28 was not found to be correlated significantly with anti-CCP2 antibodies ${ }^{15}$. In contrast, Onder $e t a t^{35}$ stated that higher DAS28 scores associated with anti-CCP positivity as discussed earlier in this study. DAS28 scores also found to be correlated significantly with RF-latex and RF-ELISA titers. Serdaroglue et $a l^{15}$ found a significant correlation between DAS28 and RF. Nevertheless, serum RF measurements have not been useful evaluative tests in RA because changes in titers generally occur slowly and often lag behind other markers of RA activity ${ }^{36}$.

This study has got its own limitations, the studied sample was relatively small, and the results of this study will be more precise if other city hospitals in Iraq were involved. Studies are required to identify patients at early stage of disease before clinical symptoms become apparent. Furthermore, the effects of therapy on antiCCP antibodies status and/or concentration are required to determine the possibility of using anti-CCP antibodies as a monitor of therapy.

\section{ACKNOWLEDGEMENTS}

We are grateful to Dr. Wameedh AlOmary/Consultant Rheumatologist and to Prof. Dr. Zainalabideen A. Abdullah (consultant immunologist, college of Medicine, University of Mosul) for their help in dealing with this subject. We are also grateful to Ibn-Sina Teaching Hospital medical staff and sub-staff for their help and to Dr. Saad Al-Husaini who performed the physical examination of the patients. 


\section{REFERENCES}

1. Herold M, Boeser V, Russe E, et al. Anti-CCP: History and its usefulness. Clin. Develop. Immunol. 2005; 12(2): 131-135.

2. Tobon GJ, Youinou P and Saraux A. The environment, geoepidemiology, and autoimmune disease: Rheumatoid arthritis. Autoimmun, 2010. Rev.; 9(5): 288292.

3. Arnett FC, Edworthy SM, Bloch DA, et al.

TheAmericanRheumatism

Association 1987 revised criteria for the classification ofrheumatoid arthritis. Arthritis. Rheum. 1988; 31:315-324.

4. Ng KP, Austin P, Ameratunga R, et al. Role of anti cyclic citrullinated peptide 2 assay in longstanding rheumatoid arthritis. APLAR J., Rheumatol 2006,9:211215.

5. Aletaha D, Neogi T, Silman AJ, et al. Rheumatoid arthritis classification criteria: an American College of Rheumatology/EuropeanLeague

Against Rheumatism collaborative initiative. Ann. Rheum. Disf 2010;69:1580-8518.

6. Westwood OM, Nelson PN and Hay FC. Rheumatoid factors: what's new?. Oxford J. Rheumatol 2006;45 (4): 379-385.

7. Goodson NJ, Fagherrra $T$ and Symmons DM. Rheumatoid Factor, Smoking, and Disease Severity; Associations with Mortality in Rheumatoid Arthritis. J. Rheumatol 2008;35;945-949.
8. Jaskowski TD, Hill HR, Russo $\mathrm{KL}$, et al. Relationship Between Rheumatoid Factor Isotypes and IgG Anti-Cyclic Citrullinated Peptide Antibodies. J. Rheumatol 2010;37:8.

9. Meyer O, Labarre C, Dougados M, et al.

Anticitrullinatedprotein/peptide antibody assays in early rheumatoid arthritis for predictingfive year radiographic damage. Ann. Rheum. Dis 2003, 62: 120-126.

10. Visser H, Cessie S, Vos K, et al. How to diagnose rheumatoid arthritis early: a prediction model for persistent (erosive) arthritis. ArthritisRheum. 2002;46:357-365.

11. Prevoo ML, van't Hof MA, Kuper HH, et al. Modified diseaseactivity scores that include twenty-eight-joint counts. Development and validation in a prospective longitudinal study of patients with rheumatoid arthritis. Arthritis Rheum 1995;38:44-48.

12. Saadeh C. The erythrocyte sedimentation rate: old and newclinical applications. South Med. JI, 1998;3:220-225.

13. Bettyr R Kirkwood. Essential of medical statistic. Black well Scientific publication. 1988 Chapter(7,8), pp:41-56.

14. Nell VP, Machold KP, Eberl G, et al. Benefit of very early referral and very early therapy with disease-modifying anti-rheumatic drugs in patients with early rheumatoid arthritis. Rheumatol 2004;43:906-914. 
15. Serdaroglu M, Cakirbay $\mathrm{H}$, Deger $\mathrm{O}$, et al. The association of anti-CCP antibodies .with disease activity in rheumatoid arthritis.RheumatolInt. 2008, 28:965-970.

16. Agyei-Frempong MT, Sakyi SA and Quansah RE. Comparison of Anti-CCP Peptide with Rheumatoid Factor and its Isotypes for Early Differential Diagnosis and Prognosis of Rheumatoid Arthritis. J. Med. Sci; 2010, 10(1):19-24.

17. Milovanoic M, Nilson E and Jaremo P. Relationship between platelets and inflammatory markers in rheumatoid arthritis. Clin. Chim. Actal; 2004, 343(1-2):237-240.

18. Pincus $\mathrm{T}$ and Sokka $\mathrm{T}$. Prevalence of normal erythrocyte sedimentation rate (ESR) and Creactive protein (CRP) on presentation of patients with rheumatoid arthritis (RA) at two rheumatology settings, one in the US and the other in Finland: Is a patient questionnaire better quantitative measure of clinical severity? Arthritis Rheum; 2005, 52(9): 127.

19. Van der Helm-Van MM AH, Verpoort KN, Breedveld FC, et al.Antibodies to citrullinated proteins and differences in clinical progression ofrheumatoid arthritis. Arthritis Res. Ther. 2005;7:R949958.

20. Bos WH, Nielen MMJ, Dijkmans $\mathrm{BAC}$, et al. Duration of prerheumatoid arthritis anti-cyclic citrullinated peptide positivityis positively associated with age at seroconversion. Ann. Rheum. Disi 2008;67:1642.

21. Makinen $\mathrm{H}$, Kautiainen $\mathrm{H}$, Hannonen P, et al. Disease activity score 28 as an instrument to measure disease activity in patients with early rheumatoid arthritis. J Rheumatoid 2007, 34(10): 19871991.

22. Li H, Song $\mathrm{W}, \mathrm{Li} \mathrm{Y}$, et al. Diagnostic value of anti-cyclic citrullinated peptide antibodies in northern Chinese Han patients with rheumatoid arthritis and its correlation with disease activity; Clin. Rheumatol 2010; 29(4):413417.

23. Schellekens GA, Visser $\mathrm{H}$, de Jong BA et al. The diagnostic properties of rheumatoid arthritis antibodies recognizing a cycliccitrullinated peptide. Arthritis Rheum. 2000;43:155-163.

24. Gupta R, Thabah MM, Aneja R, et al. Usefulness of anti CCPantibodies in rheumatic diseases in Indian patients. I. J. Med. Sci. 2009, 63(Issue 3):92100.

25. Rantapaa-Dahlqvist S, de Jong BA, Berglin E, et al. Anti-bodies against cyclic citrullinated peptide and $\operatorname{IgA}$ rheumatoid factor predict the development of rheumatoid arthritis. Arthritis Rheumi 2003;48:2741-2749.

26. Inane N, Dalkilic E, Kamali S, et al. Anti-CCP antibodies inrheumatoid arthritis and psoriatic arthritis. Clin. Rheumatol 2007, 26:17-23. 
27. Ronnelid J, Wick NIC, Lampa J, et al. Longitudinal analysis of citrullinated protein/peptide antibodies (anti-CCP) during a 5year follow-up in early rheumatoid arthritis: anti-CCP status predicts worsedisease activity and greater radiological progression. Ann Rheum Dis 2005, 64:1744-1749.

28. Domer T, Egerer K, Feist E, et al. Rheumatoid factor revisited. Curr. Opin. Rheumatol. 2004; 16:246253.

29. Hill JA, Southwood S, Sette A, et al. The conversion of arginine to citrulline allows for a high-affinity peptide interaction with the rheumatoid arthritis-associated HLA-DRB 1*0401 MHC class II molecule. J. Immunol. 2003; 171:538-541.

30. Alsalahy MM, Nasser HS, Hashem MM, et al. Effect of tobacco smoking on tissue protein citrullination and disease progression in patients with rheumatoid arthritis. Saudi Pharmaceutical J 2010;18 (Issue 2):75-80.

31. Vossenaar ER, Radstake TR, Van der Heijden A, et al. Expression and activity of citrullinating peptidylarginine deiminase enzymes in monocytes and macrophages. Ann. Rheum. Dis. 2004;63:373-381.

32. Masdottir B, Jonsson $\mathrm{T}$, Manfredsdottir V, et al. Smoking, rheumatoid factor isotypes and severity of rheumatoid arthritis. Oxford JRheumatol. 2000;39(11):1202-1205.

33. Padyukov L, Silva C, Stolt P, et al. A gene-environmentinteraction between smoking and shared epitope genes in HLA-DR providesa high risk of seropositive rheumatoid arthritis. Arthritis. Rheum 2004;50:3085- 3092.

34. Yildirim K, Karatay S, Melikoglu MA, et al. Associationsbetween acute phase reactant levels and disease activity score (DAS28) in patients with rheumatoid arthritis. Ann. Clin. Lab. Sci. 2004;34(4):423-426.

35. Onder B, Kurtaran A, Kimyon S, et al. Association of anti-CCP positivity with serum ferritin and DAS28. Rheumatol. Int 2009; 30:223-227.

36. Ward MM. Clinical and Laboratory Measures. In: William St.CE, Pisetsky, DS, Barton HF (eds). Rheumatoid Arthritis. 1st Ed, Lippincott Williams \& Wilkins, 2004, Chapter 5, pp:52-63. 


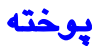

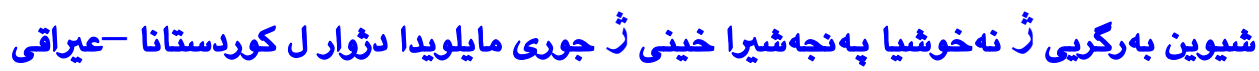

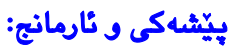

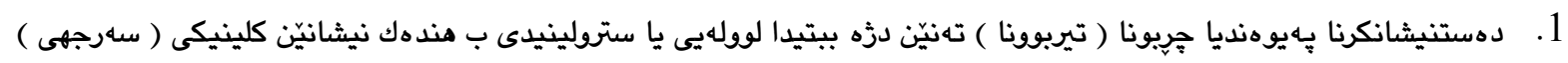 \\ وتاقيكههى بوّ مهودانا گههان بيّن بادارى .

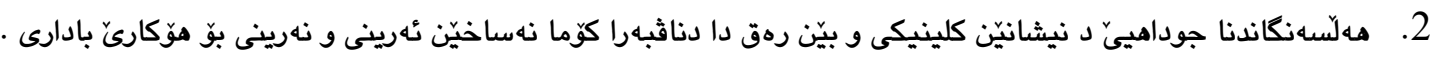

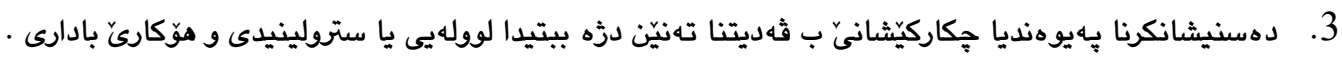

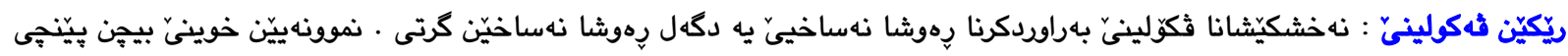

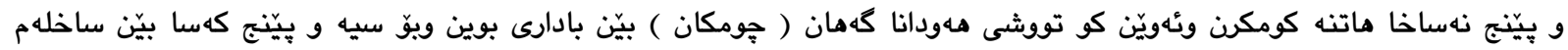

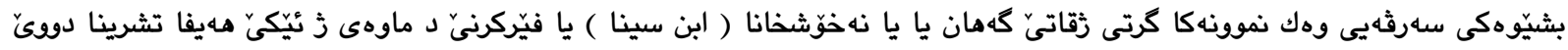

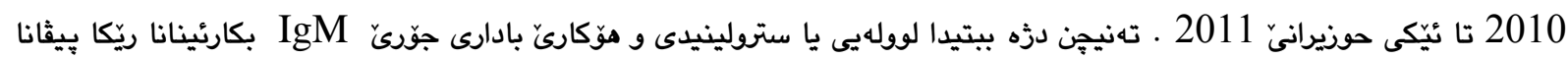

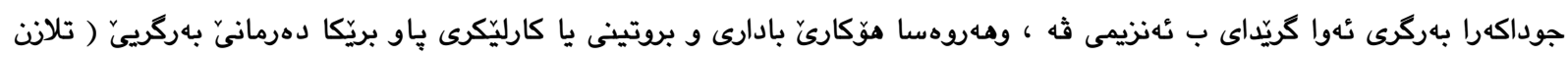

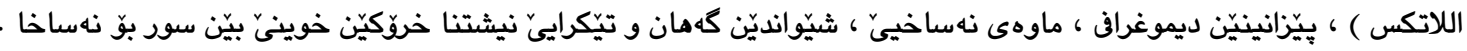
هاته تيّينيكرن كو يشكنينا تهنيّن دزه بيتيدا لوولهيى يا سترولينيدى كرايَدايه ب يهيوهنديهكا واتهيى دكهل هوّكارىّ بادارى ، سهرجهم

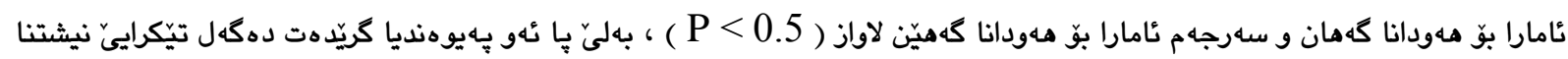

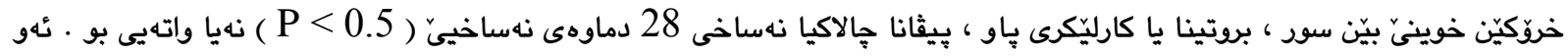

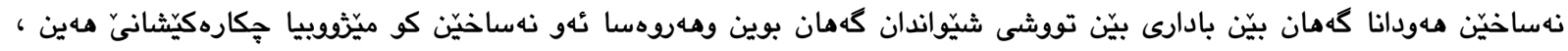

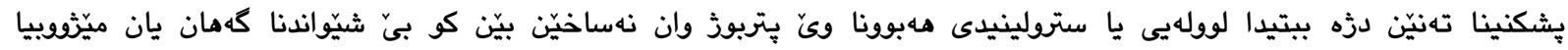

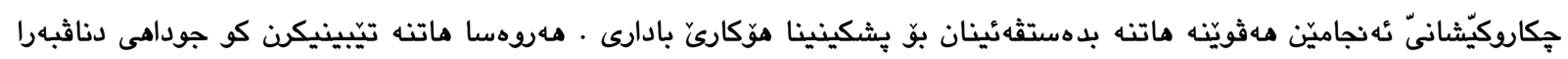

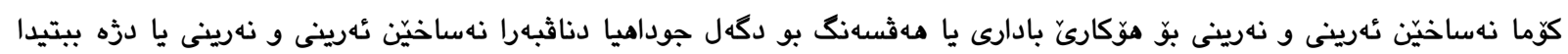
لوولهيى يا سترولينيدى ثبلى ئهو جوداهيا د يشكنينا تيّكرايى نيشتنا خروكيّن خوينى بيّن سور و بروتينا يا كارليّكرى يّاو .

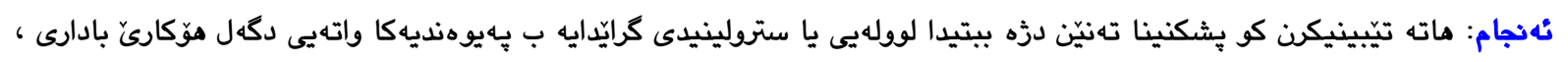

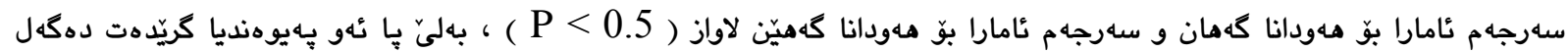

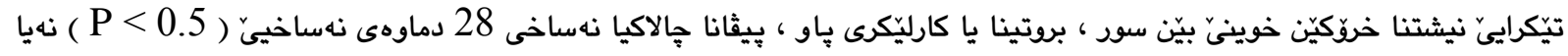

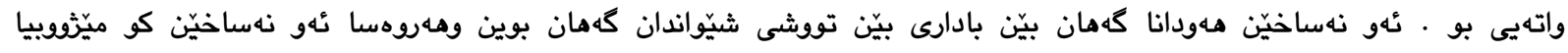

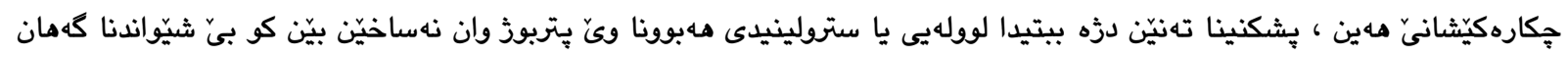

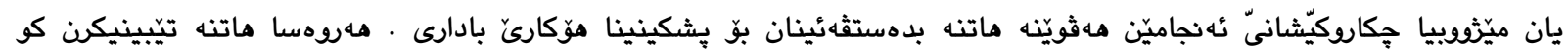

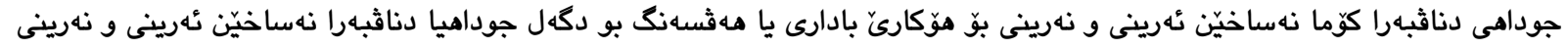

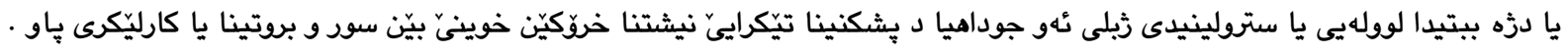

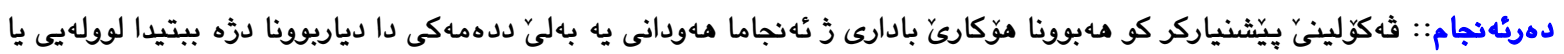

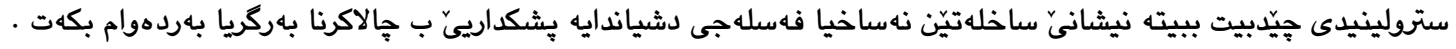




\section{الخلاصة}

تقييم علاقة المستضد للبيتيد الحلقي السترولينيدي والعامل الرثواني للفحص المختبري لالتهاب المفاصل الرثواني

الخلفية والأهداف

1. تحديد علاقة نركيز الأجسام المضادة للبيتيد الحلقي السترولينيدي ببعض الدلائل السريرية والمختبرية لالتهاب المفاصل الرثواني.

2. تقييم الفرق في الدلائل السريرية والمصلبةتين مجموعة المرضى الموجبين والسالبين لمستضد البيتيد الحلقي السترولينيدي ومجموعة المرضى الموجبين و السالبين للعامل الرثو اني. 3. تحديد علاقة التدخين باكتشاف الاجسام المضادةللبيتيد الحلقي السترولينيدي و العامل الرثو واني.

طرق البحث: تصميم الدراسة هو مقارنة الحالات المرضية مع الحالات الضابطة. تم جمع عينات الدم لخمس وخمسين

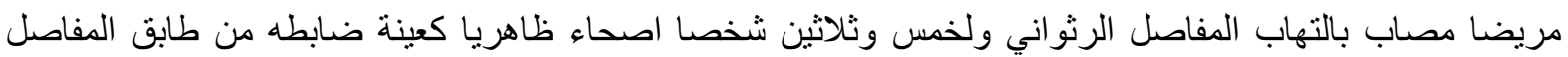

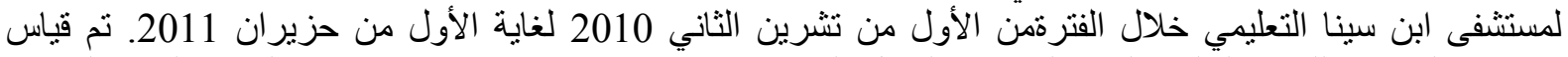

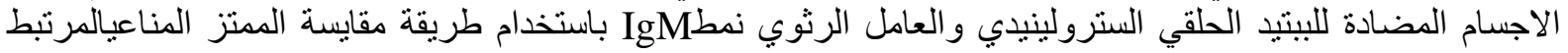

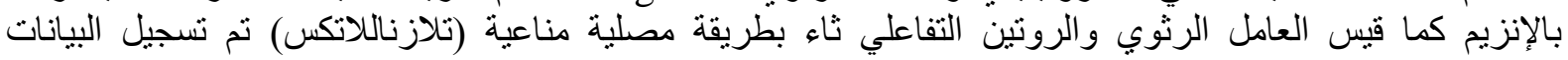

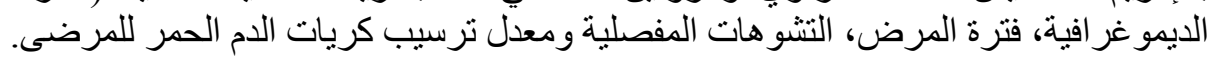

النتائج: لوحظ أن فحص الأجسام المضادة للبيتبد الحلقي السترولينبدي مرتبط ارتباطا معنويا مع العامل الرثوي, التعداد

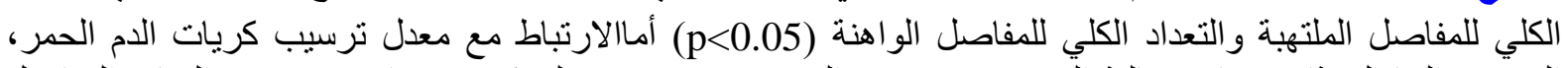

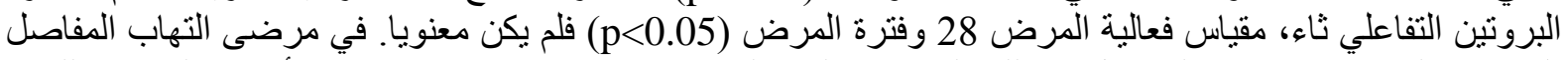

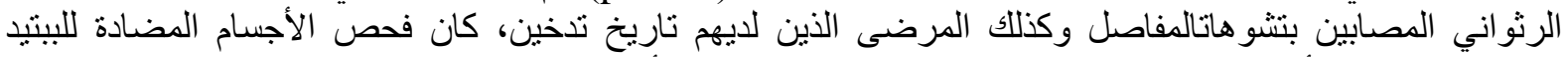

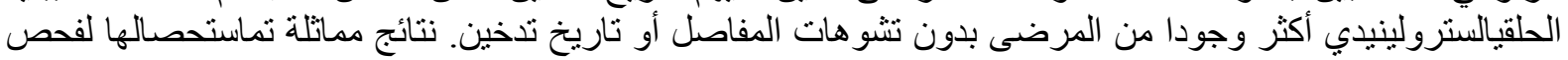

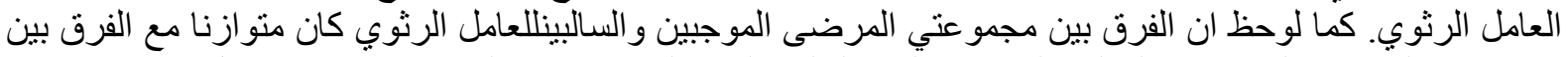

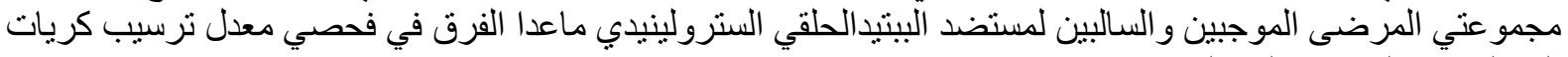
الدم الحمر و البروتين التفاعلي ثاء.

الاستنتاجات: اقترحت الدراسة أن وجود العامل الرثواني هونتيجة الالتهاب بينما ظهور مستضد البيتيد الحلقي

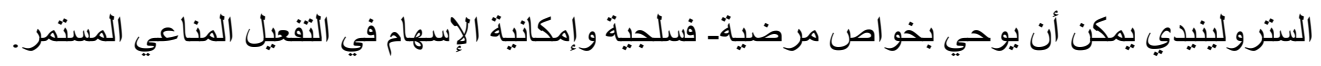

